\section{GEOPHYSICS}

\section{Three Leagues Under}

from our Soviet Correspondent

THE latest geophysical project envisaged in the Soviet Union is the drilling of a borehole into the Earth's crust-to reach, it is hoped, a depth of $15 \mathrm{~km}$ that will be more than twice as deep as any previous borehole.

This project, to be undertaken by a team of scientists from Moscow, Baku and Sverdlovsk, is led by Academician Ali A. Alizade, Director of the Baku Scientific Research Institute of the Oil Industry. The site of the proposed bore is in the Saatlov region of southern Azerbaijan. The equipment to be used is basically the standard heavy-duty 'Uralmash' drilling rig, equipped with drilling motors, drill-tubes and the latest type of bits.

In accordance with current Soviet policy, by which all research is, in theory, directed towards the needs of industry and the national economy, Academician Alizade, when interviewed by Izvestiya, stressed the practical benefits of such a project. In the course of drilling, he explains, it is likely that "petroleum and gas, deep-level heat, thermal waters, and solid ores, including polymetallic complexes" may be encountered. Yet this is, clearly, to be more than an ultradeep mining project. The research team, says Alizade, are particularly interested in the physical state of the "riches" encountered "which lie constantly in a zone of high temperatures and pressures". More general aims of the project include "the study of the deep-level structure of the Earth, investigation of the problems of the petroleum- and gasbearing capacity of mezozoic deposits, and the plotting of a detailed crosssection of the Earth's crust".

A pilot bore to the depth of $5 \mathrm{~km}$ is already in progress, and has so far reached a depth of $1.6 \mathrm{~km}$. With the main bore, a barrier of crystallinegranite and basaltic layers is expected deeper than $7.5 \mathrm{~km}$ and, apart from this, says Academician Alizade, the team are prepared for "all possible manner of surprises, which until now have remained hidden in mystery".

\section{NATURE RESERVES}

\section{Places to Visit}

THE Nature Conservancy announced last week that it has acquired a further 2,761 acres thus bringing the total area of Britain's nature reserves up to 271,404 acres. Some of the additional land will form one new reserve at Walberswick in Suffolk, and the remainder will go to enlarge the reserves at Braunton Burrows, Devon, Old Winchester Hill, Hampshire, Cavenham Heath, Suffolk,
Dyfi, Cardiganshire and Nant Irfon, Breconshire.

The new reserve at Walberswick will cover 1,211 acres, chiefly heathland, marshes and woods. Most of the reserve was signed over to the Nature Conservancy by Sir Charles Blois and the conservancy had only to purchase 95 acres. The attraction of this new reserve is that many wildfowl and wader are common visitors and shelduck are to be found there all the year round.

The largest addition announced is a further 932 acres to Braunton Burrows National Reserve in Devon; this brings the total within the reserve to 1,492 acres. Most of the new area comprises sand dunes which are rich in plant and animal life. Another eleven acres have also been added to the chalk downlands of Old Winchester Hill National Nature Reserve which is famous for its juniper scrub and wild flowers. The addition of 39 acres to the reserve at Cavenham Heath brings the total acreage to 376 .
This addition is an area called Ash Plantation-an example of damp mature fen woodland which provides a striking contrast to the dry heathland that lies nearby. Ash Plantation is rich in ferns and mosses, and it also provides a refuge for a herd of Roe deer.

Two reserves in Wales are also being enlarged with 445 acres have been added to the reserve on the estuary of the Dyfi river. The most important addition consists of 208 acres of peatland at Cors Fochno which will give botanists the opportunity of studying one of the few remaining examples of a "raised" bog. Cors Fochno is also a haven for white-fronted geese and other wildfowl.' The addition of 120 acres to the Breconshire reserve means that the reserve now covers the entire western bank and valley slope of the river Irfon near the village of Abergwesyn. The attraction of this reserve is that it is an area of sessile oak woodland, and many mountain streams and rocky crags are now included within it.

\title{
RESEARCH ASSOCIATIONS
}

\section{Change in Role Prescribed by CSII}

RESEARCH associations should concentrate their efforts on work directly commissioned by their members rather than on general cooperative research. This Rothschildian recommendation emerges from the most constructive piece of work yet undertaken by the Centre for the Study of Industrial Innovation which has turned its attention from the heady objectives of trying to identify what makes innovations succeed and fail (see Nature, 235, 366; 1971) to the bread and butter job of examining the work of research associations.

The forty research associations, whose activities range from Hosiery to Drop Forging, spent 2.2 per cent of the research budget of industry in 1968/69. This amounted to $£ 16$ million of which just over $£ 4$ million came from government grants. But since 1968 the restriction of grants from the Department of Trade and Industry has put the research associations under pressure and there is now a $£ 4$ million ceiling to government support of the associations.

In spite of this the expenditure of the RAs still grew fractionally faster than that of private industry during the $1960 \mathrm{~s}$.

But the RAs have come in for much heavy criticism from industry in recent years, and it is clear that some of the criticism has been justified.

Research associations were founded to perform cooperative industrial research but the fact that many companies feel that the associations do not meet their immediate needs is reflected in the figures for directly commissioned research undertaken by the RAs. In 1963 it formed 14 per cent of the RAs income and in 1970 only 25 per cent. This figure is rising but the report points out that it must do so if RAs are to remain a viable source of technical help for industry.

The RAs which tend to be most effective, according to the report, are those in areas with less rapidly advancing technologies-for example in the clothing, construction and non-ferrous metals industries, where the work done by the research associations accounts for 10 per cent of all the research and development done in these industries.

The report also calls for a review of the government's grant system. Grants should be given for more specific purposes, according to the CSII, perhaps to finance a core of basic work in the research associations, as distinct from the customer-contractor work that should form the bulk of their research.

But while the past activities of the research associations do not emerge in a halcyon light from the CSII's scrutiny (although the institute is careful to point out that not all the associations are at fault), the industry which the associations are meant to serve does not emerge as perfect. Some of the dissatisfaction of industry with the associations is due to companies misunderstanding what the associations are for. The belief that paying the subscription entitles companies to a supply of attractive and instantly usable technical results is a mistaken one. The report says that each company should ensure that it in fact takes the necessary steps to derive the maximum value it can from membership of an association. 